Огляди літератури, оригінальні дослідження, погляд на проблему, короткі повідомлення UDC 612.015.11/.348+616-008.6]-02:616.12-008.331.1-06:616.37-002.2

DOI 10.11603/1811-2471.2017.v0.i2.7661

\title{
HOMEOSTATIC DISORDERS IN PATIENTS WITH COMBINATION OF HYPERTONIC DISEASE AND CHRONIC PANCREATITIS
}

\author{
@L. Babinets, I. Medvid, I. Herasymets, I. Borovyk \\ I. Horbachevsky Ternopil State Medical University
}

SUMMARY. The signs of compensatory mechanisms disruption and increased autonomic nervous system imbalance with a decrease in ductility autonomous processes in the load were determined in patients with hypertonic disease upon accession the concomitant chronic pancreatitis. The combination of pathologies is also accompanied by manifestations of endogenous intoxication, significant violations of antioxidant and kallikrein-kinin systems.

KEY WORDS: hypertonic disease; chronic pancreatitis; autonomic nervous system; heart rate variability; antioxidant system; kallikrein-kinin system; endogenous intoxication.

Introduction. Patients with hypertension have accompanying pathology in $58.4 \%$ of cases. This determines the relevance of research processes maintaining homeostasis with a combination of various diseases $[1,5]$.

The aim of the study - to examine and compare the character of vegetative, antioxidant, kallikreinkinin system and parameters of endogenous intoxication disorders in the patients with combination of hypertonic disease (HD) and chronic pancreatitis (CP).

Materials and Methods. The study involved 40 patients with HD and concomitant $\mathrm{CP}$ in nonremission phase, 15 healthy people. The middleaged was $(47.7 \pm 1.2)$ years. Research of autonomic regulation conducted by definition of standard statistical and spectral heart rate variability (HRV) [3]. Laboratory research of standard parameters of antioxidant, kallikrein-kinin systems and the severity of endogenous intoxication were conducted.

Results. Here vegetative background of $65.0 \%$ of patients was appropriate to eutonia, $25.0 \%$ sympathicotonia, $10.0 \%$ - vagotonia. Also at comorbidity a significant reduction in total power of spectre (TP $\left.-(678.6 \pm 90.3) \mathrm{ms}^{2}\right)$, component nervous of heart rate regulation ( $\mathrm{HF}-(16.55 \pm 1.57) \%, \mathrm{LF}-$ $(19.83 \pm 1.61) \%)$ and increase in humoral and metabolic effects (VLF - $(63.63 \pm 3.00) \%)$ were observed.

The laboratory data in patients shows a reduction of antioxidant protection of the body: superoxide dismutase - $(39.83 \pm 0.50) \mathrm{U} / \mathrm{ml}$ erythrocytes; reduced glutathione - $(38.86 \pm 0.64) \mathrm{mmol} / \mathrm{l}$; catalase (45.24 \pm 1.37$) \%$; medium molecular size peptides (MMSP) with a maximum absorption at $254 \mathrm{~nm}-$

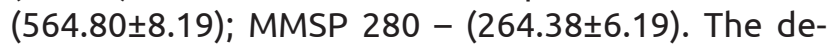
gree of proteolytic system activation was $(48.26 \pm 1.52) \mathrm{mmol}$ of arginine $/(\mathrm{h} * \mathrm{l})$. The overall breakdown of proteins was also stimulated by more active kininogenase that is displayed by the increase of the kallikrein $((182.48 \pm 1.37) \mathrm{mcmol} /(\min * l))$, decrease of its inactive precursor content (prekallikrein $-(50.39 \pm 1.73) \mathrm{mcmol}$ of arginine $\left./\left(\mathrm{min}^{*}\right)\right)$ and inhibitor $\quad a_{2}$-macroglobulin $\quad((1.77 \pm 0.04) \mathrm{g} / \mathrm{l})$. Decrease of kininase II $((173.44 \pm 2.81) \mathrm{mcmol} /$ $\left.\left(\mathrm{min}^{*} \mathrm{l}\right)\right)$ show the weakening of incentive mechanisms in the body against kinins overproduction. Increased activity of the kallikrein-kinin system at comorbidity of HD and CP causes the enhances inflammation and swelling of the pancreas.

Received data changes of HRV in patients with HD were compared with results of other studies. It is established that as the disease progresses happens development of left ventricular hypertrophy and fibrosis in the myocardium with decrease of $\beta 1$ receptors density. That causes decrease in statistical power and spectral performance [4]. Confirmed that oxidative stress plays an important role in the pathogenesis of HD and CP [2], but data about the features of antioxidant protection with a combination of these diseases was not enough. Another study confirmed that the accession of concomitant gastroenterological diseases (chronic non-calculous cholecystitis) while HP led the growth of endogenous intoxication [5]. Reduced production of kinins at HD also was confirmed by a number of studies [3].

Conclusions. Reduction of reducing total power spectrum, increasing the share of humoral-metabolic effects on heart rate, tendency to asympathicotonia autonomic reactivity, lower levels of superoxide dismutase, glutathione, prekallikrein, $\sigma_{2}$ macroglobulin, kininase II, higher levels of catalase, middle molecular peptides, total proteolytic activity of plasma kallikrein were observed in the patients with combination of hypertonic disease and chronic pancreatitis. 
Огляди літератури, оригінальні дослідження, погляд на проблему, короткі повідомлення

\section{LITERATURE}

1. Babinets L. S. The imbalance of the autonomic nervous system in the patients with comorbidity of hypertonic disease and chronic pancreatitis / L. S. Babinets, I. I. Medvid, I. I. Herasymets // Lek. Obz. - 2014. - № 63 (6). - P. 512-513.

2. Cohen R. A. Vascular oxidative stress: the common link in hypertensive and diabetic vascular disease / R. A. Cohen, X. Tong // J. Cardiovasc. Pharmacol. - 2010. № 55 (4). - P. 308-316.

3. Farmer S. G. (1991). Pharmacology of bradykinin receptors in bradykinin antagonists: basic and clinical research / S. G. Farmer, R. M. Burch - N.Y. : Marcel Dekker Inc. - P. 1-32.

4. Mikhailov V. M. Heart rate variability. Experience of the practical application of the method / V. M. Mikhailov. Ivanovo, 2000. $-200 \mathrm{p}$.

5. Zinevych Ya.V. Features of the endogenous intoxication in patients with hypertension, coronary heart disease and concomitant chronic cholecystitis. Ukrainska medytsyna / Ya. V. Zinevych, O. I. Osadcha // Ukraine Medicines. - 2010. - № 2. - P. 56-58.

\section{REFERENCES}

1. Babinets, L.S., Medvid, I.I., \& Herasymets, I.I. (2014). The imbalance of the autonomic nervous system in the patients with comorbidity of hypertonic disease and chronic pancreatitis. Lek Obz., 63 (6), 512-513.

2. Cohen, R.A., Tong, X. (2010). Vascular oxidative stress: the common link in hypertensive and diabetic vascular disease. J. Cardiovasc. Pharmacol., 55 (4), 308-316.

3. Farmer, S.G., \& Burch, R.M. (1991). Pharmacology of bradykinin receptors in bradykinin antagonists: basic and clinical research. N.Y.: Marcel Dekker Inc., 1-32.

4. Mikhailov, V.M. (2000). Heart rate variability. Experience of the practical application of the method. Ivanovo, 200.

5. Zinevych, Ya.V., \& Osadcha, O.I. (2010). Features of the endogenous intoxication in patients with hypertension, coronary heart disease and concomitant chronic cholecystitis. Ukrainska medytsyna - Ukrainian Medicine, 2, 56-58.

\title{
ГОМЕОСТАТИЧНІ ПОРУШЕННЯ У ПАЦІЄНТІВ ІЗ КОМОРБІДНІСТЮ ГІПЕРТОНІЧНОЇ ХВОРОБИ ТА ХРОНІЧНОГО ПАНКРЕАТИТУ
}

\author{
๑Л. С. Бабінець, І. І. Медвідь, І. І. Герасимець, І. О. Боровик
}

ДВНЗ «Тернопільський державний медичний університет імені І. Я. Горбачевського МОЗ України»

PЕзЮМЕ. У пацієнтів із гіпертонічною хворобою при приєднанні хронічного панкреатиту виявлено ознаки порушення компенсаторних механізмів і підвищення дисбалансу вегетативної системи зі зменшенням пластичності адаптаційних процесів. Поєднання патологій також супроводжувалось проявами ендогенної інтоксикації, порушеннями антиоксидантної, калікреїн-кінінової систем.

КЛючОВІ СлОВА: гіпертонічна хвороба; хронічний панкреатит; вегетативна нервова система; варіабельність серцевого ритму; антиоксидантна система; калікреїн-кінінова система; ендогенна інтоксикація.

\section{ГОМЕОСТАТИЧЕСКИЕ НАРУШЕНИЯ У ПАЦИЕНТОВ С КОМОРБИДНОСТЬЮ ГИПЕРТОНИЧЕСКОЙ БОЛЕЗНИ И ХРОНИЧЕСКОГО ПАНКРЕАТИТА}

\author{
๑Л. С. Бабинец, И. И. Медведь, И. И. Герасимец, И. О. Боровик
}

ГВУз «Тернопольской государственный медицинский университет имени И. Я. Горбачевского МОз Украины»

PЕЗЮМЕ. У пациентов с гипертонической болезнью при присоединении хронического панкреатита выявлены признаки нарушения компенсаторных механизмов и повышение дисбаланса вегетативной системы с уменьшением пластичности адаптационных процессов. Сочетание патологий также сопровождалось проявлениями эндогенной интоксикации, нарушениями антиоксидантной, калликреин-кининовой систем.

КЛЮЧЕВЫЕ СЛОВА: гипертоническая болезнь; хронический панкреатит; вегетативная нервная система; вариабельность сердечного ритма; антиоксидантная система; калликреин-кининовая система; эндогенная интоксикация. 